\title{
HEALTH PROBLEMS IN THE MERCHANT NAVY
}

BY

\author{
G. JAMESON CARR
}

London

Before the present war, in July 1939, the gross tonnage of the mercantile shipping of the British Empire amounted to $24 \frac{1}{4}$ millions, or some 30 per cent. of the world's tonnage. The United States of America came next with over 12 million tons; followed by Japan, $5 \frac{1}{2}$ millions; Norway, $4 \frac{3}{4}$ millions, Germany, $4 \frac{1}{2}$ millions; and France and the Netherlands each just under 3 million tons. The shipping industry has contributed more to our prosperity than any other single industry, yet the personnel did not exceed 180,000 before the war. The large majority of these men are employed in ships without surgeons. This fact is relevant in that the conditions under which surgeons are required may explain the fact that, up to date, the medical profession has had little opportunity to influence health conditions amongst merchant seamen. Surgeons are only appointed under the Shipping Act where over 100 persons are on board, or when there are over 50 emigrants. So it is obvious that seamen in the majority of ships below 10,000 tons and with less than 100 on board-and these constitute perhaps 75 per cent. of the total tonnage-are mainly dependent upon first-aid treatment at the hands of captains or stewards.

The growth of reasonable amenities and good conditions of employment in the Merchant Navy-the Mercantile Marine-has always been slow. Public opinion has played little part in their development, largely because of the lack of knowledge on the part of non-seagoing persons. As in other industries established before the middle of last century there is a long record of exploitation. But man-power was never lacking. Wretched quarters, the scanty and sometimes bad rationing, and cruel beatings, did little to deter men from the sea. Even to-day there is no established supervising medical authority to advise on crews' quarters, diet, ventilation, lighting and other matters concerned with health. Enterprise in this respect is a matter for individual owners who for the most part restrict themselves to strict regulations under the Act. Until recently the only means of communication between various countries was by water, and that still remains the chief method of transport of heavy merchandise. This is likely to be even more important in the future.

The sea as a calling is the most hazardous of all large group activities, except perhaps that of the

F soldier on active service. Before the change from sail to steam the mean annual death rate of 64 per 10,000 in the British Mercantile Marine was five times greater than that of other hazardous industries such as coal-mining and quarrying. This figure has now been reduced to 19.9 per 10,000 (1937), but is still in excess of the rate in coal-mining and quarrying which lies between 11.5 and 12.5 per 10,000 . The figures during this war are not available, but Table 1 shows the loss of life amongst U.K. merchant seamen from 1935 to 1937.

TABLE 1

LOSS OF LIFE AMONG MEMBERS OF THE CREWS OF U.K. MERCHANT VESSELS, 1935-37

\begin{tabular}{|c|c|c|c|c|c|c|}
\hline \multirow{2}{*}{ Year } & \multicolumn{2}{|c|}{ No. employed } & \multicolumn{2}{|c|}{$\begin{array}{l}\text { Deaths due } \\
\text { to accident }\end{array}$} & \multicolumn{2}{|c|}{$\begin{array}{l}\text { Deaths due to } \\
\text { disease, homi- } \\
\text { cide or suicide* }\end{array}$} \\
\hline & $\begin{array}{l}\text { British } \\
\text { only }\end{array}$ & $\begin{array}{l}\text { In- } \\
\text { cluding } \\
\text { foreign } \\
\text { subjects } \\
\text { and } \\
\text { Lascars }\end{array}$ & $\begin{array}{c}\text { British } \\
\text { only }\end{array}$ & $\begin{array}{c}\text { In- } \\
\text { cluding } \\
\text { foreign } \\
\text { subjects } \\
\text { and } \\
\text { Lascars }\end{array}$ & $\begin{array}{c}\text { British } \\
\text { only }\end{array}$ & $\begin{array}{l}\text { In- } \\
\text { cluding } \\
\text { foreign } \\
\text { subjects } \\
\text { and } \\
\text { Lascars }\end{array}$ \\
\hline 1935 & 126,700 & 182,500 & $\begin{array}{c}265 \\
(20.9)\end{array}$ & $\begin{array}{c}323 \\
(17 \cdot 7)\end{array}$ & $\begin{array}{c}268 \\
(21 \cdot 1)\end{array}$ & $\begin{array}{c}467 \\
(25 \cdot 6)\end{array}$ \\
\hline 1936 & 130,830 & 185,970 & $\begin{array}{c}190 \\
(14 \cdot 5)\end{array}$ & $\begin{array}{c}236 \\
(12 \cdot 7)\end{array}$ & $\begin{array}{c}322 \\
(24 \cdot 6)\end{array}$ & $\begin{array}{c}499 \\
(26 \cdot 8)\end{array}$ \\
\hline 1937 & 133,110 & 190,690 & $\begin{array}{c}265 \\
(19 \cdot 9)\end{array}$ & $\begin{array}{c}328 \\
(17 \cdot 4)\end{array}$ & $\begin{array}{c}281 \\
(21 \cdot 1)\end{array}$ & $\begin{array}{c}464 \\
(24 \cdot 3)\end{array}$ \\
\hline
\end{tabular}

\section{Catastrophes and Accidents at Sea}

Catastrophic events at sea may be caused in the following circumstances: collision with icebergs; collision with ships; grounding on rocky coasts with heavy seas; and fire. In addition, many accidents of a minor nature may be expected, such as injuries to passengers and crew through ship hit by heavy seas causing bodily injuries to persons on board; seamen falling from aloft or down holds; explosion in boiler compartments; and injuries by contact with moving machinery.

The risk of collision with icebergs has lessened considerably since the Titanic disaster on April 14, 1912, when the ship foundered after hitting an iceberg, causing the deaths of 1595 passengers and crew-711 persons being rescued. The advent of the International Ice

* Figures in brackets indicate the rate per 10,000 . 
Patrol in the ice season, together with the development of continuous wireless watches on shipboard, has enabled shipping to be fairly accurately informed of the presence of dangerous ice, though the combination of ice and fog usually found in the danger area is still a menace which can never be overlooked. Collision with ships is a danger which occurs in all parts of the world, especially in those latitudes where fog is prevalent. Here again the hazard is becoming less owing to the universal use of wireless, and the fact that in all ships of modern design the crews are no longer 'housed' in the forecastle where impact usually takes place. Grounding on rocky coasts in heavy seas is less common during recent years due to the use of modern navigational appliances such as Fathometers, directional wireless and submarine signalling apparatus. Storm, fog, ice and fire are, therefore, the greatest menaces at sea and often entail unavoidable death and injury. Obstacles to rescue are sometimes insuperable: it has been impossible to launch lifeboats or to pass life-lines even where rescuers are more than willing to risk their own lives Inaccessability, or being out of range, may also be a serious obstacle to succour. The accurate charting of the seas has resulted in well-defined sea routes for all ships except those engaged in exploration and adventure, so now there are few occasions when a ship is completely outside the sphere of aid.

Certain hazards affect all ships alike whether large or small, but the personnel and equipment required to contend with them is not the same. For instance firefighting equipment in modern ships of large tonnage is highly efficient; not only are ordinary fire extinguishers provided and $\mathrm{CO}_{2}$ cylinders for holds, but there is 'Foamite' for oil in the engine-room, and an automatic thermostatic system of sprinklers through the ship. In addition there is the Richardio, the latest method of firealarm signalling. Fire alarm stations are manned day and night; alarms and signals are led by wire pipes and telephone to the bridge; and from here all valves are coupled to $\mathrm{CO}_{2}$ bottles in stores, holds, baggage and mail room. The modern lifeboat is now motor-driven and in the event of abandoning ship freezing is prevented by thermostatic methods of electrical heating and starting. One latest device is the gravity davit for launching lifeboats. For prevention against grounding the Echometer or Fathometer determines water depths with great accuracy. The present war has been responsible for the invention of devices which make a most remarkable contribution to life-saving from hazards formerly considered as irreducible. For example the Loran, used for long-range navigation by wireless rays from coast stations, works by beam interception and actually plots the position of the ship at any time or place in the course of a vessel crossing an ocean, and the Asdic, an instrument which detects objects under water, has a range of several miles.

\section{Medical Personnel}

Board of Trade inspectors and Lloyds' surveyors are appointed to see that the statutory regulations are observed; they do not make recommendations, neither do the Board of Trade medical inspectors. Port Health Authorities are eminently qualified to make recommendations on health conditions for seamen but lack the necessary authority to do so. So it rests with those companies with initiative and an enlightened sense of obligation to the seamen to suggest and improve conditions such as crews' quarters. As long as their improvements do not interfere with the safety of the ship they meet with no objection from the Board of Trade.

The ship surgeon is one of the persons who should be most active in this respect. He should make recommendations on all matters of hygiene and health, but in practice he rarely does so except in minor matters and chiefly with regard to his own sick bay and medical equipment. Above all others he should be competent to criticise and recommend improvements, but the fact is that he is rarely qualified to do so. Unlike conditions of service in the Merchant Navy of at least three other nations the British ship surgeon is not required to attend courses in ship hygiene and other relevant subjects. He learns mainly by experience, and is effective in his work only if he happens to be interested in the sociological and preventive aspects of this branch of industrial medicine. So it is vitally important that properly authorized schemes of training be set up wherever possible under the aegis of a University. Schemes of training would apply, in the main, to permanent ship surgeons-only about 300 in peace-time, but a sufficient number nevertheless to warrant action being taken at the earliest possible opportunity. Although over 1000 other ships employ temporary surgeons, voyage by voyage, it is unlikely that these doctors would be willing to undergo special training before employment, nor indeed would it be necessary.

The Board of Trade appoints medical inspectors of ships, whose duty is 'to inspect the medicines, medical stores and antiscorbutics with which a ship is required by this part of the Act to be provided.' The Board also appoints medical inspectors of seamen. By this part of the Act application is made by the master of any ship for a medical inspector to examine any seaman applying for employment. Medical inspectors are also appointed to inspect steerage passengers and crew about to proceed in emigrant ships. In this capacity the inspector is required by the Immigration Officer 'to see that none of the crew or steerage passengers appear to be, by reason of any bodily or mental reason, unfit to proceed or likely to endanger health or safety of the other persons likely to proceed in the ship.'

The Board of Trade also requires that 'every foreign-going ship having 100 souls on board shall carry on board as part of her complement some duly qualified medical practitioner'-the ship surgeon. In Sect. 303 of the Shipping Act the following instruction is found: 'A duly authorized medical practitioner shall be carried on board an emigrant ship when the number of emigrants exceeds 50; and also where the number of persons on board (including cabin passengers, officers and crew) exceed 300 .' The person authorized to ratify the appointment of both ship surgeons and medical 
inspectors is the Emigration Officer, a layman. Here is an example of the need for revision.

\section{Hospitals and Sick Bays}

'The spaces set apart for hospital accommodation shall be on or above the uppermost passenger deck and shall be properly divided off from other living quarters to the satisfaction of the emigration officer and the Board of Trade medical officer at the port of construction or clearance.'

These are the regulations for ships carrying doctors. All liners are furnished with hospitals for passengers and crew which are fairly adequate. Space allotted for this is usually far in excess of Government requirements. But the isolation hospital is still being housed on the aft poop, where the thrashing of propellers and the pitch and roll in bad weather are hardly conducive to the rest and quiet of a fevered patient. In any case there is no scientific evidence to show that infectious patients require that extreme measure of isolation, and in a few modern ships their accommodation adjoins the general hospital. On most liners there is a departure from regulations where hospitals are housed midships below decks.

In freighters-ships from, say, 1000 to 10,000 tons - which are not required to carry a surgeon, our British practice falls behind that of some other nations. There is no statutory requirement for a sick bay. Some, but not many, enlightened companies do provide this; but it is rarely adequate nor is it well placed. Infectious cases were and are frequently isolated by placing them in the lifeboats and long usage of such practice has blunted the sensibility not only of owners but of the men themselves. Attempts to administer first-aid treatment in the restricted surroundings of the crews' quarters in the forecastle are commonly ineffective. Imagine the plight of a man with a fractured femur in such surroundings, or the man with pneumonia where posture and complete rest are equally imperative; here they are submitted to the maximum movement of the ship, to the incidental noises of winch and chain, to the disturbance caused by change of watch and to a smoke-laden atmosphere. If the provision of permanent quarters is impracticable then the ships should be so planned as to permit the conversion midships of a room which might, when not in use for patients, be used for storage. In large freighters the example of the U.S.A., Norway and Australia might be followed; they arrange permanent quarters for a sick bay with accommodation according to numbers. But in existing small ships even this requirement may be impossible. In all new ships some change is imperative; there must be convertible quarters for small ships, and a sick bay for larger ships with beds in proportion to numbers of crew.

\section{Problems of Smaller Ships}

In the big liners there are adequate hospitals and the medical personnel includes one, two or even three doctors, with dispensers, male hospital orderlies and nurses in addition. Here conditions are good, both for medical staff and crew. But there is a large number of cargo ships-comprising all varieties of craft from coasters to foreign-going ships up to 10,000 tons-whose total tonnage far exceeds that of ships required to carry surgeons and with good amenities. These present a real problem: The facilities for first aid vary widely from ship to ship, but for the most part they are inadequate. Some ships may have doctors, but the great majority do not and we have seen that here there is no statutory requirement for sick-bay accommodation. It is as arbitrary to conclude that all ships below 8000 tons are without surgeons as it is that all above do employ them, but this represents a good basis for discussion. This large number of ships is split up into small, independent and almost isolated groups, and makes uneconomical in most of them the employment of a doctor and all that that appointment entails-assistants, equipment and a sick-bay. A similar problem is also found in the smaller factories and group activities ashore, but with this profound difference: skilled medical attention is, almost everywhere ashore, quickly available for any emergency. That is why first aid afloat assumes an importance peculiarly its own; first aid, in fact, may mean the only aid and therefore extends to routine treatment. For that reason the service of first aid at sea demands most careful scrutiny. Accidents on board ship, in themselves, present no more unusual feature or problem than those encountered ashore. But the skill, intelligence and experience of the man rendering first aid, owing to the unusual locus and the difficulty of obtaining early professional assistance, is a matter of signal importance.

Our immediate and present concern should therefore be directed to improving the medical facilities for foreign-going freighters which comprise 75 per cent. of our tonnage. The coasters have their own problems, but except in unusual circumstances, aid is within their easy reach; in most countries they have always shore stations at their service through wireless communication, and these can readily provide for all medical contingencies. The number involved is, in any case, relatively small. Whatever reforms are suggested must be practicable and easy to enforce, and must win the co-operation of owners. The financial outlay can readily be justified by greater efficiency. Changes must be acceptable to crews and, if possible, uniform throughout the shipping world despite the difficulty of language.

Freighters are required to carry certain drugs and stock mixtures and medical stores according to Scale II of the Shipping Act, * itself a document of much interest-to the medical historian. Masters are required to have the St. John or St. Andrew

* Some of the drugs itemized in the Captain's Medical Guide are: alum, amyl nitrate, pulv. digitalis, lot. hydrarg. nig., creosote (for dental caries), liq. plumb. subacet., tr. opii, pot. bromide, pot. chlor., sulphur. rotund., and ung. ac. boric. Frequently these drugs may have to be administered by laymen, and more often than not insufficient directions are given, nor is there adequate instruction in their use. 
Ambulance Certificate. The captain in ships without surgeons is regarded as the person responsible for the sick and injured man. This has a formidable disadvantage since in times of emergency he must first attend to the safety of his ship. It is therefore the custom for him to delegate his medical obligation to one of the officers, or more usually to the steward. It has been suggested for any foreign-going ship that a petty officer might be appointed to do this duty or some other rating, usually unspecified, who would combine this duty with others. In any real emergency however the only rating in a small crew who could be spared and diverted to this duty is the steward, and the chief objection is that he is wholly untrained for this post. He receives instructions from the captain but is allowed no responsibility; he has to refer to the captain when in difficulties, and this is not a commendable procedure in a time of emergency at sea. It is therefore suggested that in ships with no doctor the master should be relieved of all direct responsibility for medical and surgical care of the sailor. The steward on such ships could well be given this responsibility on the condition that he undergoes a three months' course on lines similar to those for sick-berth attendants of the Royal Navy.* The 'Pool' system would make it easy for such a man to attend these courses.

There is another alternative. Retired Royal Navy sick bay petty officers might be offered the opportunity to undertake this work. This rating is of proved value in other types of industry, in factories for instance, as a member of the medical service provided, and in passenger ships he is invaluable. To get over the difficulty of adding a new rating to small ships he might undergo a course in stewardship. Less objection would be forthcoming from the freighter companies if they were not required to make an addition to their personnel, for reasons of space and finance. The institution of a special diploma for Merchant Navy sick-berth attendants is a possibility. There may be objections to this but its possession would at least imply a certain amount of education and intelligence, without which it would be impossible to understand and follow out instructions at sea provided in an up-to-date Medical Manual. A new Manual, comprehensive and up to date is essential. If possible it should be on an international basis.

\section{Pre-employment Medical Examination}

As a preliminary to any recommendations being made about the treatment of the merchant seaman it must be remembered that to sign on an unfit man, or a partially disabled man, is to contract a wholly

* At the Royal Naval Hospital at Chatham, for example, he could obtain suitable instruction including tuition in hygiene; he could work in the hospital to get practical experience in the dressing of wounds and burns, and the management of sick and injured men in the wards. Points to be stressed would be the importance of posture in the treatment of fractures and dislocations, the significance of dyspnoea in acute conditions such as pneumonia, the meaning of oedema, the avoidance of bed sores, and the nursing of unconscious patients. There would be instruction in the methods of administering drugs, injections, enemata and of passing catheters. Some knowledge of invalid cookery would be most important. unnecessary liability. The medical and personal problem is complicated by his presence on board. Engagement of a crew therefore becomes a matter of much importance and is the intimate concern of preventive medicine. The man with heart disease, nephritis, epilepsy, venereal disease or chronic rheumatism, or with disablements such as hernia, varicose veins or flat feet may, in the event of any major catastrophe, be a definite embarrassment and even a menace in a small ship's company. His condition may in certain circumstances be such as to precipitate a catastrophe, and his presence on board is often fiercely resented by his mates. A primary requisite, therefore, of any improved health service is an adequate system for ensuring preemployment examination, including chest radiography.

Effects of the Merchant Navy Pool. As this war developed the demands of both industry and the fighting service threatened the man supply of the Merchant Navy. The Pool in the first instance was intended as a source of man-power. If some measure had not been taken to hold men to their sea service by a shore subsistence wage many of them would have drifted into the fighting services or the factories. The periods in port when loading and unloading ships and for repairs, involve shore idleness of crews from days to weeks. The Essential Work (Merchant Navy) Order, 1941, established a definite service which men could not leave except for bad health, disablement or serious misdemeanour.

In order to provide fit men medical examination centres were established at certain large ports. There all applicants for service in the Merchant Navy are medically examined, except those who are being engaged by shipping companies which prefer to select and examine their own men. But there are certain defects in this system and these need amendment. After the first examination for the Pool a man may have various illnesses. Because of the lack of follow-up examination at definite intervals these frequently develop unknown to the authorities or, it may be, to the man himself. Only in the event of discharge from a ship for sickness or disablement (and in the event of that man being signed off the Pool), or where a man ashore is called up and reports to the Pool obviously ill, would there be a note inserted on the health record. The high mortality rate due to sickness (see Table 1) is, like the accident mortality rate, evidence of failure to eliminate applicants quite unfitted for the sea. The Pool as it is fails to obtain reliable information or morbidity rates; and so it enables the doctor to do little by way of prevention of ill-health.

\section{Crews' Quarters}

One of the most important health provisions for merchant seamen is adequate living quarters in the ship. Overcrowding in quarters is a potent factor in the spread of disease. Wood (1942) has shown that seamen arrive for treatment for tuberculosis in a more advanced stage of the disease than do the 


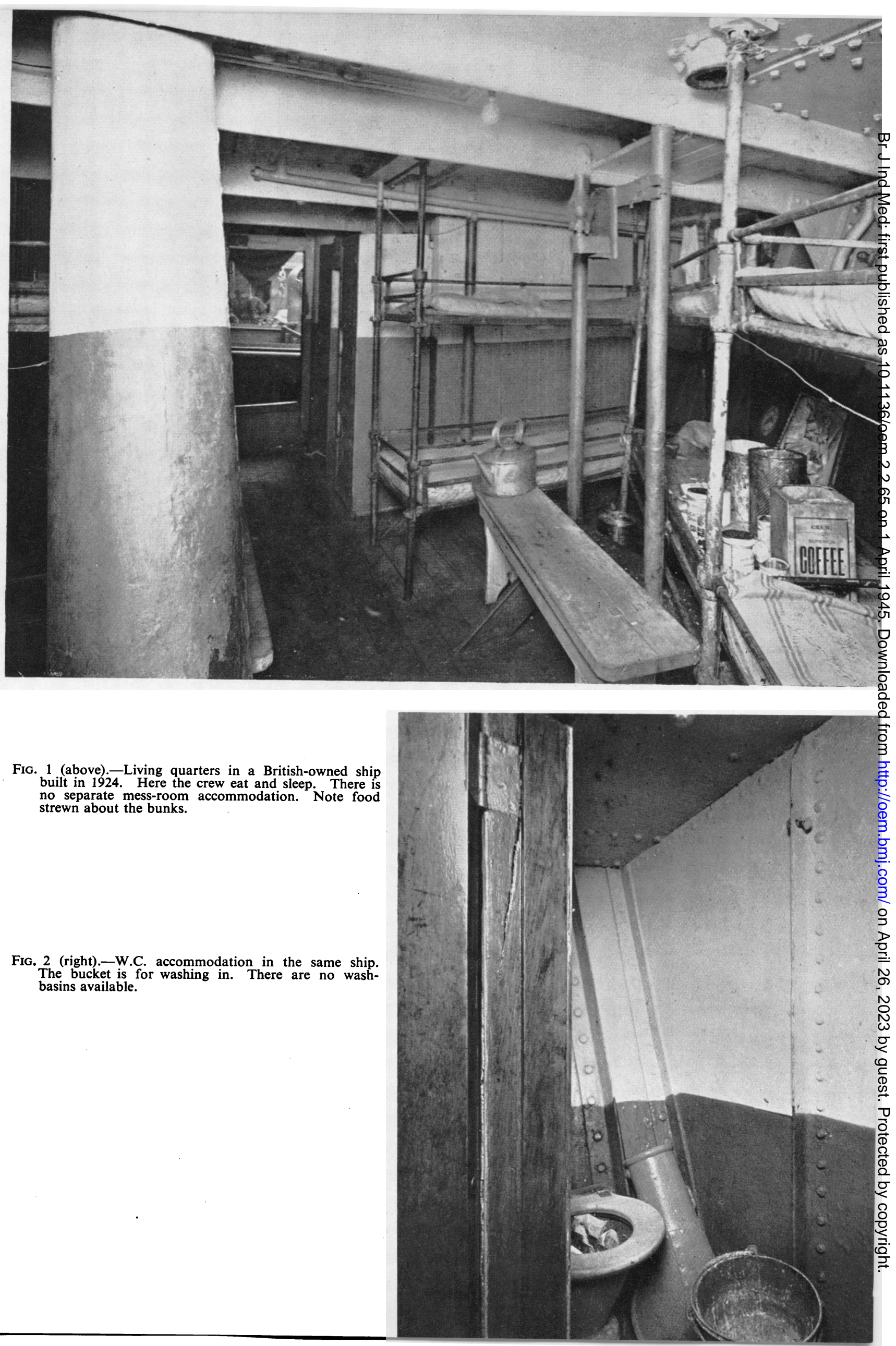




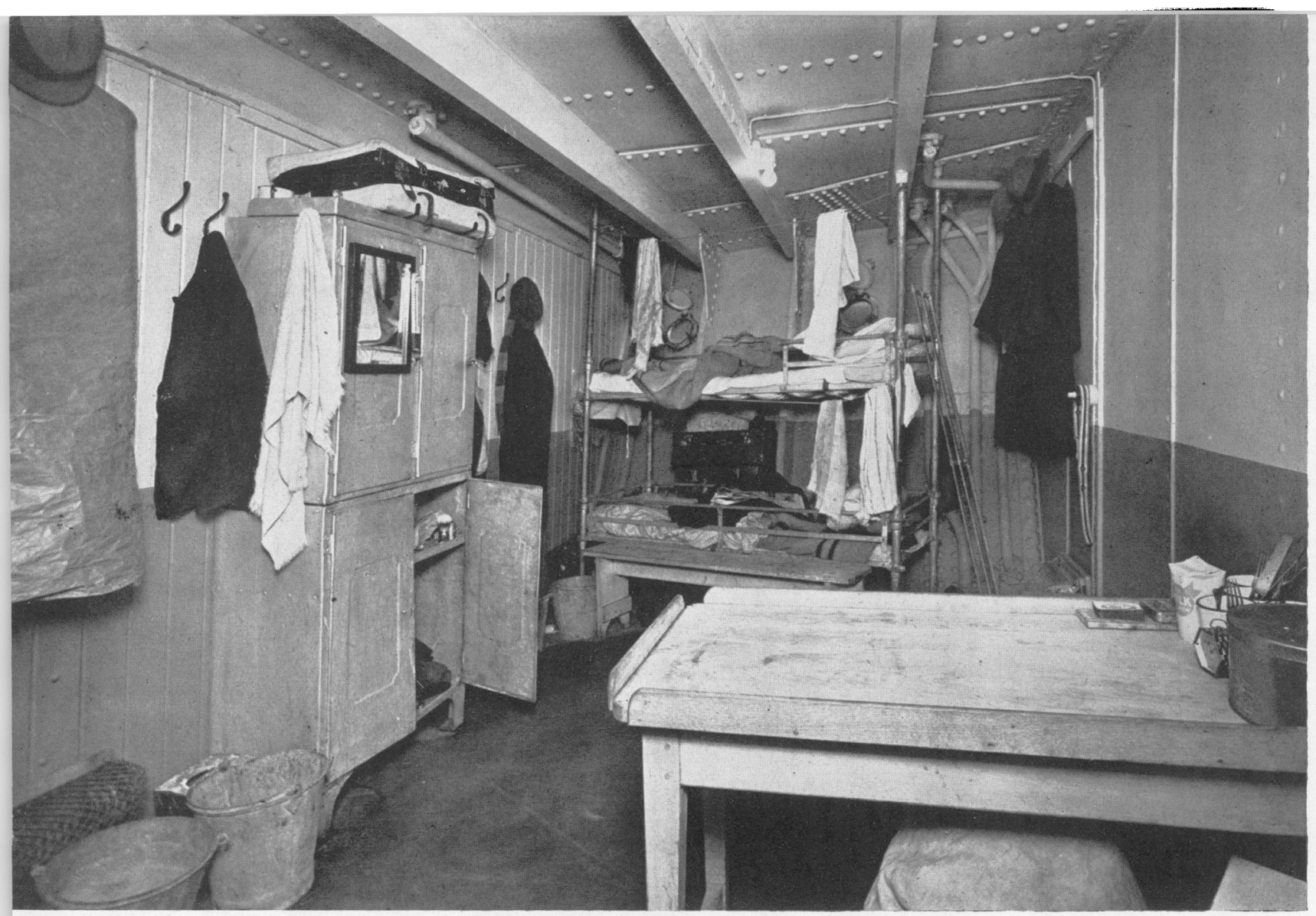

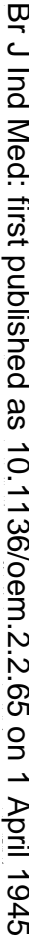

FIG. 3 (above).-A typical picture of the average conditions in a modern British cargo vessel. Here is the sleeping accommodation in a four-berth cabin.

FIG. 4 (below).-Washing and W.C. accommodation in the same ship. Note lack of privacy. The wash-basins have only cold salt water laid on.

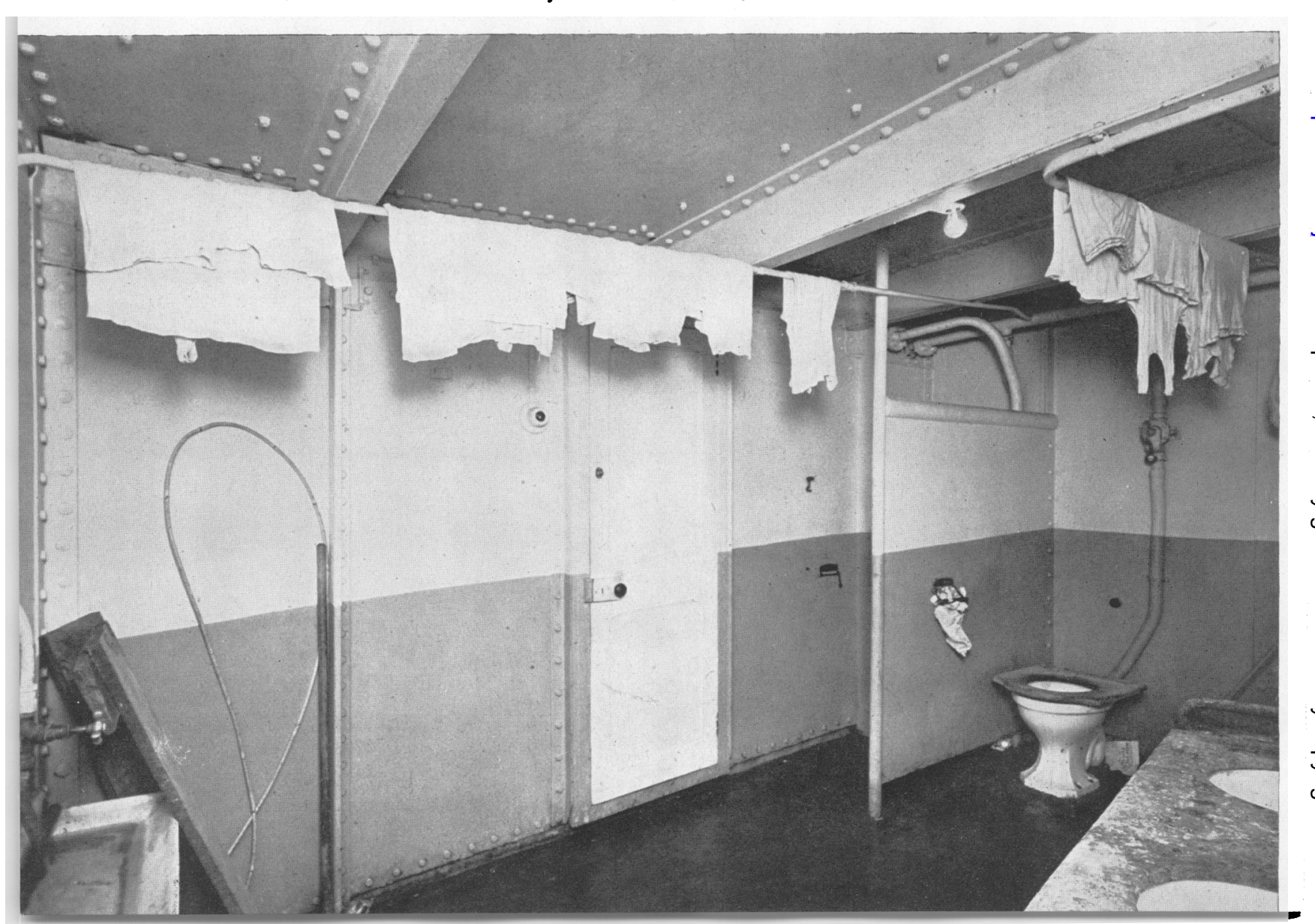




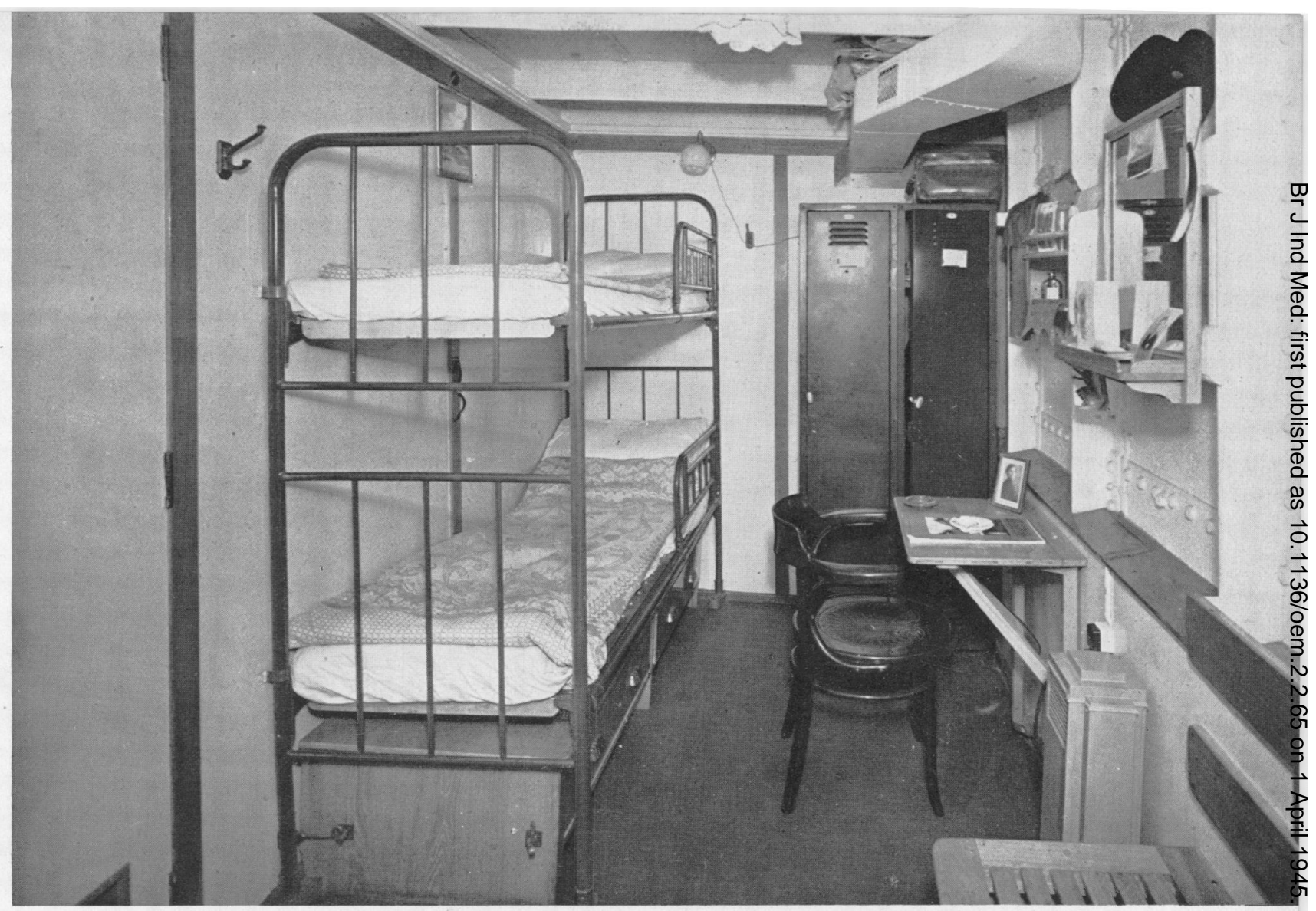

FIG. 5 (above).-A two-berth cabin in a British cargo vessel built in 1936. These are standard for all the seamen on board. Note the full-length locker for each man. There is an obvious impression of cheerfulness.

Fig. 6 (below).-The mess-room in the same ship. Each man has his own chair instead of backless forms found in 99 per cent. of ships.

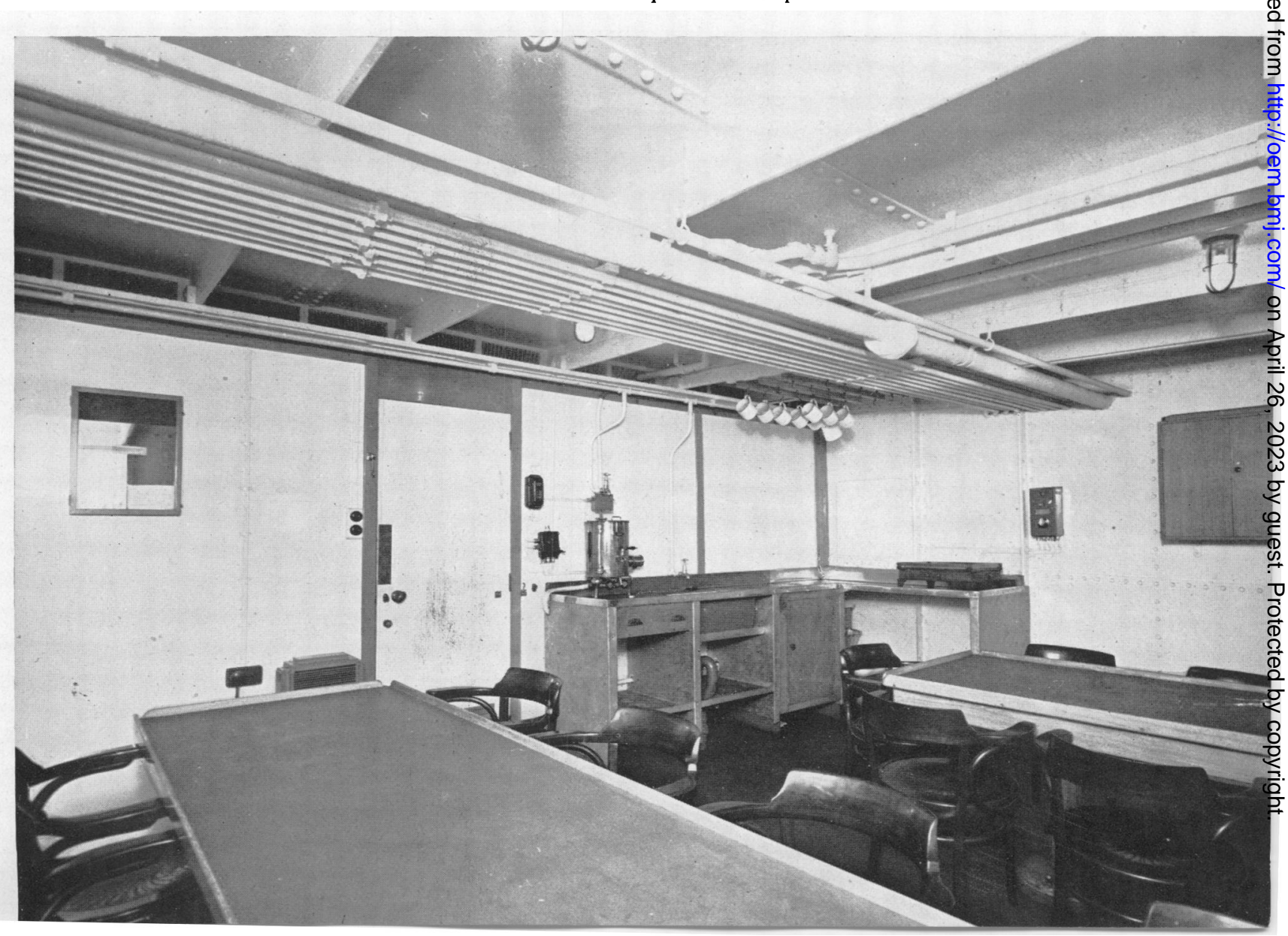




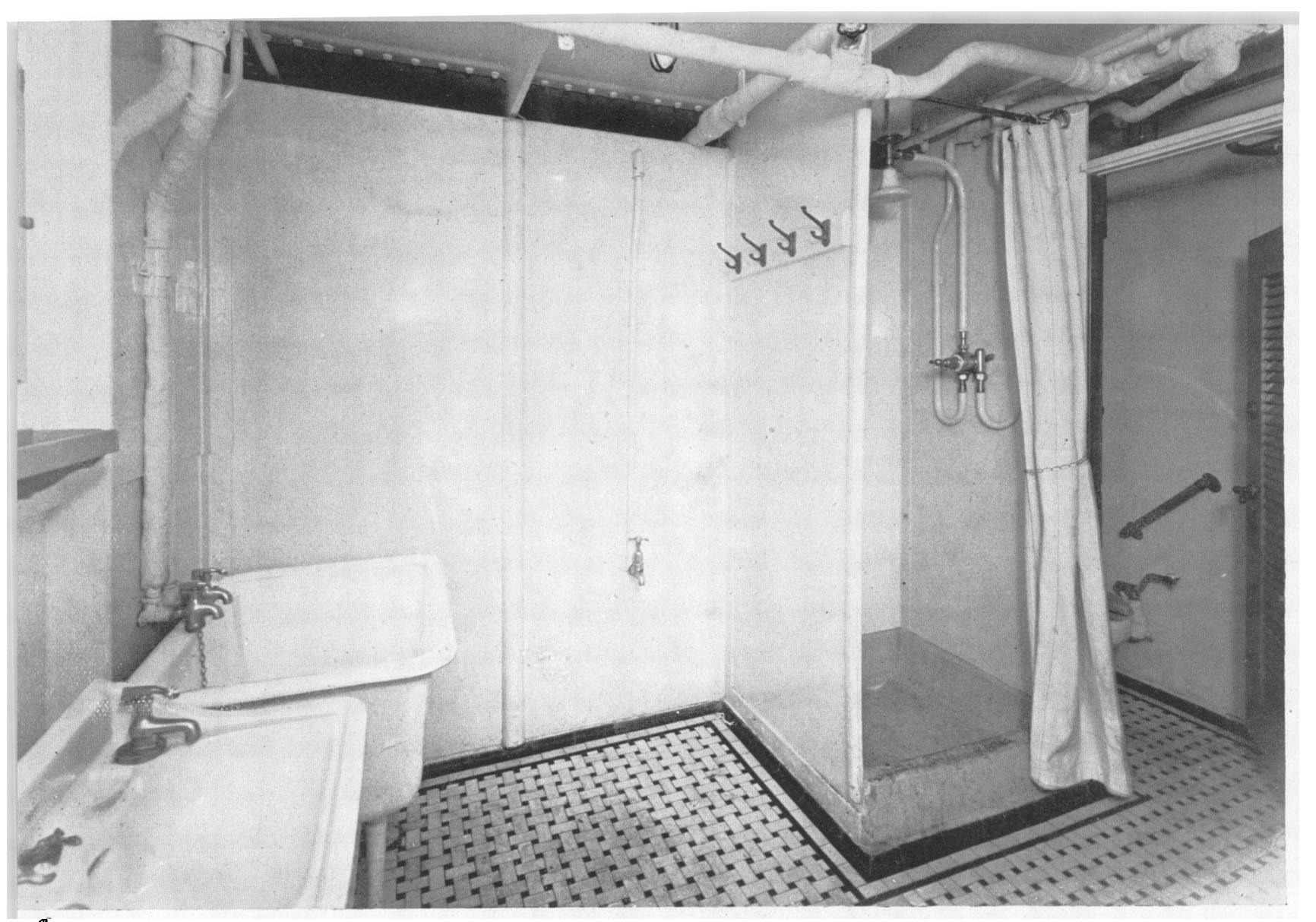

FIG. 7 (above).-Washing and bathing accommodation for the crew in the same ship as Fig. 5. These are ideal and could not be improved. Hot and cold fresh water always available. Curtains provide privacy.

FIG. 8 (below).-Washing accommodation in a foreign-owned ship. Hot and cold fresh water always available The large tank above the basins contains 800 gallons of electrically heated water with thermostatic control.

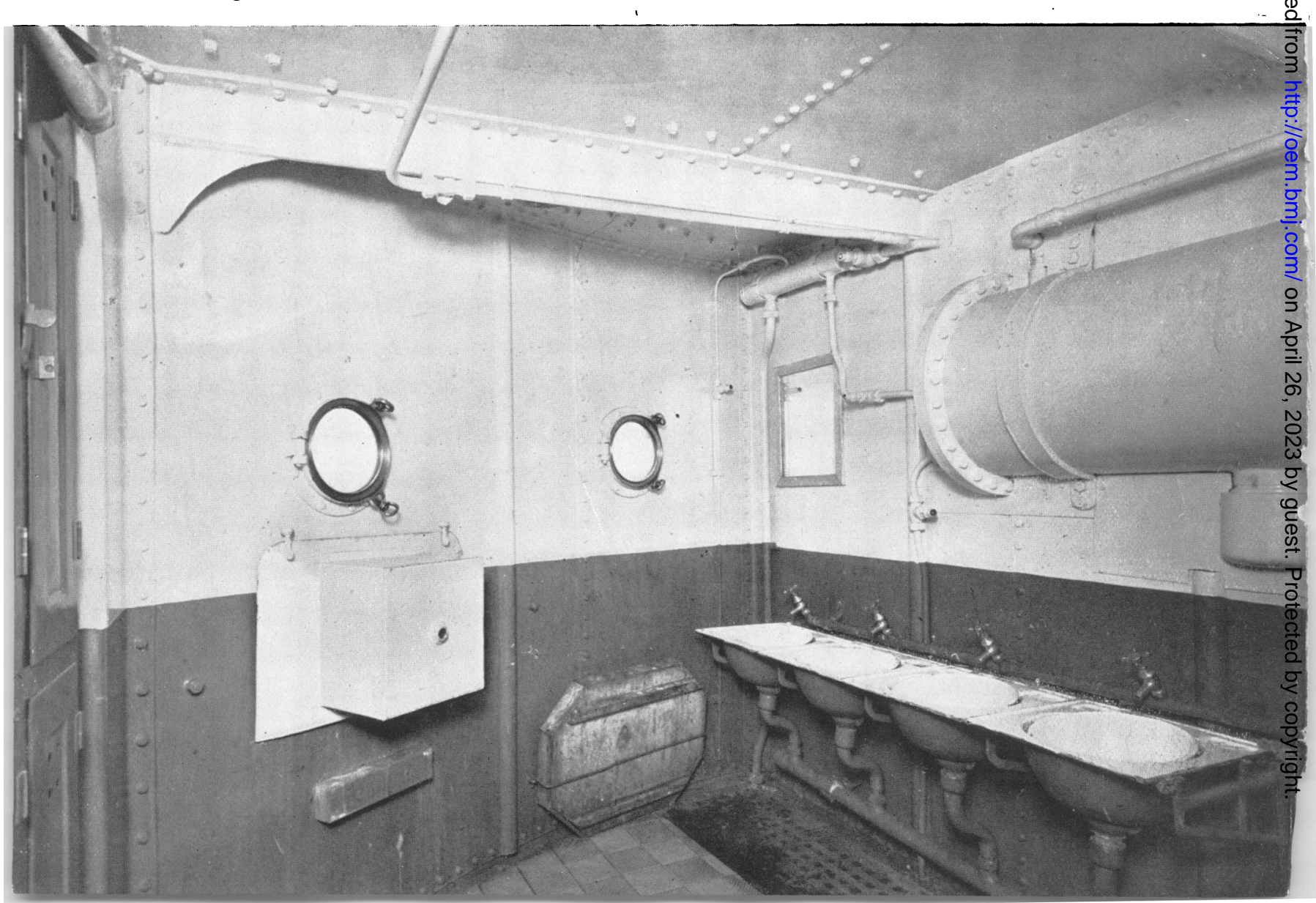


general population. He considers that unsatisfactory living conditions at sea, and overcrowding in particular, are a main reason for this. Earlier diagnosis could be achieved by routine radiography. Frazer (1936) in a report to the Liverpool Port Sanitary Authority points out that much can be done by competent inspection to improve conditions. In Liverpool all vessels entering the port are visited as soon as possible after docking. Quarters are inspected and inquiries made on matters such as the health of the crew during the voyage, the source of the water supply, the condition of tanks and bilges and whether any sick or dead rats have been found. Unsatisfactory conditions are reported in writing to the captain. Black (1945) has surveyed the problem of crew accommodation in the Merchant Navy. During 1942 and 1943 he examined in detail the quarters provided in 60 British merchant ships for 1857 seamen. He found that ships built since 1937 provide better quarters than those built previously; in some cases they were excellent. But in some of them the regulations of the Board of Trade were being loosely enforced. The improvements most needed are an increase in the space standard in sleeping quarters, and some scheme whereby plans for quarters in new ships should be passed by a medical officer with experience, before construction is started. Illustrations of both good and bad quarters are given in figs. 1-8.

\section{Communication by Wireless}

If the captain of a ship with no doctor is in some medical difficulty he sends out a wireless message in the hope that he may get advice or even personal aid from another ship carrying a doctor. This method of communication is now simplified by the use of code. In the International Code of Signals 1931, the medical section includes three parts: quarantine; case-taking system; diseases and description of condition. The case-taking system at a first glance seems formidable, but is a simple and clear method of sending a message in order to get a medical opinion. If the instructions in its use are carefully followed the necessity for crossquestions and answers will be largely eliminated. Communication between alien tongues is through associated code words but has frequently given rise to absurd misunderstandings. There is still some difficulty with regard to the advice that may be given owing to the lack of international agreement on medical technical matters. The metric system, for example, is not yet universal. Advice on specific treatment cannot be given through the Code, so the only alternative at present is to give a diagnosis and refer the captain or his deputy to his own Medical Guide. This unsatisfactory state of affairs will remain until international agreement is reached on the various points which have been raised in this paper.

\section{Summary and Conclusions}

Adequate methods of training ship surgeons should be provided. This is part of the development of industrial medicine and should be University responsibility. At the present time the ship surgeon has little interest in preventive and social medicine. He should pay special attention to the hygiene of the ship, for example crews' quarters.

The majority of ships in the Merchant Navy have no surgeon, so in such cases specially trained first-aid attendants should be provided. If necessary they should also act as stewards. Courses of training for sick-berth attendants should be instituted, and ex-R.N. personnel considered where appointments are being made.

Pre-employment medical examination in the Merchant Navy is essential and should be developed to include measures such as chest radiography. It must also include an adequate follow-up scheme.

Special attention to matters such as sick-bay space and site, crews' quarters, mess-rooms, lavatory accommodation, ventilation and lighting, should be paid by ship builders in the future. All plans for new ships should be scrutinized by a competent medical authority.

There is need for a new Maritime Medical Manual, international in scope. Drugs, instruments, and other medical equipment in ships should be brought up to date. Methods of communication on health matters at sea should be simplified and improved.

\section{Acknowledgement}

Thanks are due to Dr. W. M. Frazer, Medical Officer of Health and Port Medical Officer of Health, Liverpool, for permission to reproduce the photographs of crews' quarters.

\section{REFERENCES}

Black, S. A. B. (1945), Publ. Hlth, 58, 40 Frazer, W. M. (1937). Ann. Rept. to the Liverpool Port Sanitary Authority for 1936, p. 62 .

Registrar-General's Decennial Supplement, Eng. and Wales, 1931. Wood, J. E. (1942) Occupational Mortality. (1938). H.M.S.O. Lond. 